\title{
China and Ireland Economic and Finance Cooperation
}

\author{
Ann Derwin
}

Before my arrival in China as Ambassador of Ireland, like anyone else embarking on a posting to the Middle Kingdom, I spent a lot of time becoming acquainted with the different aspects of the bilateral relations between Ireland and China.

While I expected to see a positive and robust relationship, I was still struck by the sheer variety of areas in which Ireland and China cooperate. Very high among these areas was of course our relationship as trading and economic partners.

Irish and Chinese economies have much in common-economies previously heavily reliant on agriculture, which have been transformed in a relatively short space of time into highly advanced and technologically innovative economies. Both our governments place a great emphasis on education and innovation as a means to raise living standards. We are both determined to add our own unique skills and competencies to the advancement of the global economy.

Ireland and China are also two of the few countries who recorded GDP growth in 2020 despite the challenges of COVID-19.

\section{Bilateral Trade Flows}

Aligned with our commonalities, we have witnessed continual growth in our trading relationship in the decades since the establishment of diplomatic relations in 1979. This growth has increased rapidly in the last number of years with bilateral trade in goods and services rising from approximately EUR 7 billion in 2013 to over EUR 24 billion in 2019.

Despite the current pandemic, we continue to enjoy very strong trade flows. The year 2020 witnessed approximately EUR 16.8 billion in trade in goods comprised of

\footnotetext{
A. Derwin $(\varangle)$

Embassy of Ireland to the People's Republic of China, Beijing, China 
over EUR 10.5 billion in Irish exports to China and EUR 6.2 billion in imports from China to Ireland. This represents an impressive 18\% year on year growth from 2019.

As well as an active flow of goods and services in both directions, Ireland also engages actively on the ground with China through its extensive physical Team Ireland presence. At present, Ireland is represented by our Embassy in Beijing, our resident Consulates General in Shanghai and Hong Kong and our State agencies across the cities of Beijing, Shanghai, Hong Kong and Shenzhen.

Enterprise Ireland, the IDA, Bord Bia and Tourism Ireland all play a major role in actively promoting Ireland in China and raising awareness of our country and its wide range of unique offerings across a multitude of sectors.

Enterprise Ireland is the government organisation responsible for the development and growth of Irish enterprises in world markets by working in partnership with Irish companies to help them start, grow, innovate and win export sales in global markets.

IDA Ireland's main objective is to encourage investment into Ireland by foreignowned companies. Bord Bia, Ireland's food promotion agency is responsible for bringing Ireland's outstanding food, drink and horticulture to the world, thus enabling growth and sustainability of producers. Tourism Ireland is responsible for marketing the island of Ireland overseas as a leading holiday destination.

In many cities across China, Ireland's Embassy, Consulate and State agency representatives work hard to promote Ireland and Irish businesses and companies introducing top-quality Irish produce to Chinese audiences. From trade and investment exhibitions, seafood and food and beverage trade fairs to education Expos and cultural promotion events, Team Ireland maximises both physical and increasingly virtual events and opportunities to promote Ireland.

Ireland has enduring relationships with China's top international trade fairs, with participation in both the China International Import Exhibition (CIIE) in Shanghai and the China International Fair for Trade in Services (CIFTIS) in Beijing in recent years.

In terms of Chinese investment into Ireland, we continue to witness very strong growth in this area. Chinese foreign direct investment (FDI) into Ireland rose by 56\% to EUR 130.5 million in 2019. 2020 saw further major Chinese investment into Ireland with Huawei expanding its Irish operations in terms of investment and employment and TikTok announcing in 2021 that it intended on establishing its first European data centre in Ireland as part of a EUR 460 million investment into Ireland.

The Irish Government, with strong engagement from its Chinese counterpart, intends to capitalise on the extensive complementarities between, on the one hand, China's national economic priorities as set out in its 14th Five-Year Plan, and on the other hand, the strengths that Ireland has to offer. Ireland's particular strengths lie in innovation, entrepreneurship, science and technology including R\&D, higher education, high technology including green, clean and FinTech, financial services, food, agri-science and food safety systems. 


\section{Research and Development}

Outside of trade flows, there are also many compatibilities between Chinese and Irish economies. Many of the highest priority areas contained in the recently announced 14th Five-Year Plan such as sustainable urbanisation, innovation, research and development, green development and regional development are areas, in which key Irish policy makers have a keen interest. Furthermore, in many of these areas, Ireland is highly ranked in global rankings.

Ireland's global rankings in research and development have risen sharply in recent years with particularly strong performances in the following areas:

No. 1 ranking in Nanotechnology,

No. 2 ranking in Animal and Diary Science and Immunology,

No. 2 ranking in Computer Science,

No. 3 ranking in Animal Husbandry and Dairy Science, and

No. 5 ranking in Materials Science.

Irish higher education institutes are very much a part of the research and development ecosystem in Ireland and linked to this are their relationships with fellow educational institutes around the world. In terms of Ireland-China educational collaboration, there are now more than 200 joint higher education programmes between educational institutes in China and Ireland.

Additionally, a revised memorandum of understanding to promote cooperation on science, technology and innovation was signed between Ireland and China in July 2019. This will allow our countries deepen our relationships in the area of research and innovation, which is also essential to deliver on our shared ambitions to become global innovation leaders.

Enduring people-to-people links between Ireland and China are very much in evidence in the education field in the thousands of students in Ireland and China, who seize the opportunity to study in our respective countries annually.

\section{Financial Services}

Expertise in internationally traded specialist financial services has been a core part of Ireland's offering to the world for over three decades. Ireland's proven capabilities across international banking, insurance, aviation financing, FinTech and payments and asset management and fund services industries have been a constant source of growth and pride.

Connecting international asset managers from around the world with clients from 70 countries illustrates how Ireland's wider financial services sector operates as a gateway to Europe-we use our skills to build success for our partners and ourselves.

In April 2019, the Government of Ireland launched Ireland for Finance, its wholeof-Government strategy for the further development of the international financial 
services sector in Ireland to 2025. The vision of the strategy is for Ireland is to be a top-tier location of choice for specialist international financial services.

The employment target for the strategy is to reach 50,000 people in direct employment in the sector by 2025 . This compares with 44,000 people directly employed in the sector at the end of 2018 .

The strategy is structured around the following four pillars:

1. The operating environment pillar focuses on ensuring the policy, culture and legislative conditions underpinning international financial services will support growth.

2. The technology and innovation pillar focuses on providing a collaborative approach to addressing emerging challenges and opportunities in technological developments.

3. The talent pillar seeks to ensure that we continue to have skilled people to meet the demands of the international financial services sector, including meeting new and changing skills.

4. The communications and promotion pillar focuses on ensuring that Ireland's international financial offering is communicated to all those who are or may be attracted to investing in Ireland.

Three horizontal priorities apply across the four pillars: regionalization, sustainable finance and diversity.

The Ireland for Finance Strategy also recognises that organisations that are diverse improve collaboration and drive better financial performance by harnessing the power of different experiences, knowledge and skills. Within this space, gender diversity plays a crucial role and can enhance the process and quality of decision-making.

Crucial to building success in the long term is sustained investment in knowledge and relationships. Ireland can, and increasingly will, provide inbound access to investment managers looking to deploy capital in the Chinese securities marketsthe previous work of industry participants around the Stock Connect infrastructure and grant of RQFII quota to Ireland in late 2016 are testament to this.

Just as important, the rapid development of asset management capabilities in China will naturally seek new markets and client bases to extend and increase the size of their international businesses. Ireland, as a global centre for asset management and fund services, is ready to assist in this journey.

\section{Green Finance}

In relation to Green Finance, the Irish Government has long recognised the importance of this area with Ireland being among the first countries to make Green Finance a strategic priority, with Government policy backing since 2012.

The Irish Government's National Mitigation Action plan includes as a specific action the need to explore how to best attract domestic and international capital towards the financing of our decarbonisation efforts. 
However, as well as the very important role that Green Finance has to play with regard to supporting our decarbonisation efforts, so too does it present exciting opportunities. This is even more pertinent as the sustainable finance initiative at the EU level gains momentum.

Since arriving in China, I have read and heard much about China's efforts in this area, and I believe this is an area of much potential partnership for both Ireland and China.

\section{FinTech}

Irish FinTech exports to China have increased significantly over the last five years with more Irish FinTech companies entering the Chinese market than ever before. Some of China's largest financial institutions and organisations currently use Irish FinTech solutions. These include Bank of China, ICBC, HSBC, RBC, Hong Kong Jockey Club, Sensetime, and Bytedance.

Ireland's FinTech capabilities are wide ranging, but Irish FinTech is particularly strong in two key areas-RegTech and Payments-with exports to China in these areas continuing to exhibit strong growth. Irish RegTech companies have established a world-class reputation for helping financial services customers deal with the increasingly complex and rapidly evolving regulation-as well as continuous disruption and transformation-which characterises the industry today including in the Chinese market. The Irish RegTech Cluster includes highly regarded Irish companies such as Fenergo, Know Your Customer, Daon and MyComplianceOffice all entering the Chinese market.

In the Payments area, Ireland also comes out as a world leader with Irish companies such as Fexco, Taxback International, CurrencyFair, MiFinity and Ding leading the charge. Irish payments companies are partnering with Chinese payment companies in order to enhance the Europe-China payments corridor. Examples of such partnerships include:

- CurrencyFair, a leading provider of International Money Transfer services to consumers and businesses worldwide recently announced a major expansion into China through the signing of a strategic partnership with Hong Kong-based Convoy Payment, a subsidiary of Convoy Global Holdings, and

- MiFinity, another Irish remittance company, is licensed to acquire UnionPay traffic and support a cross border remittance service via UnionPay MoneyExpress.

More broadly, Ireland is renowned as a centre of global financial services with hundreds of the world's leading financial services firms currently operating in Ireland and $40 \%$ of the world's hedge fund assets being serviced by Ireland. Ireland currently ranks fourth globally in terms of export of financial services.

One of the most recent success stories in terms of Irish FinTech companies in China is that of Global Shares. Global Shares is the fastest growing Irish FinTech company in China at present and is one of only a handful of companies worldwide 
that offer fully outsourced employee share plan management working with public and private companies through employee equity FinTech and share-dealing solutions. Having established its first office in Hong Kong in 2018 and an office in Beijing in 2019 , Global Shares has displayed phenomenal growth, and it is evidence that much more potential exists for their rapid growth in the Chinese market.

\section{Women in Business, Finance and Entrepreneurship in Ireland}

Diversity in business and finance is also a major priority for Ireland as we believe that it is crucial in order to best reflect the modern and globalised society in which we live. It is also vital to delivering a more sustainable and inclusive economy for us all. In order to better cultivate a more gender-diverse business environment in Ireland, our State trade promotion agency, Enterprise Ireland, introduced an action plan for Women in Business in January 2020. Ireland believes that increasing the participation of women in establishing, leading and growing enterprises will result in better business and more rapid and sustainable long-term economic growth.

The action plan is based on four pillars:

1. Increasing the number of women-led established companies growing internationally,

2. Increasing the number of women in middle and senior management and leadership roles in Irish companies,

3. Increasing the number of women becoming entrepreneurs (we are investing in a national network of role models to interact with and inspire future entrepreneurs), and

4. Increasing the number of women-led start-ups with high growth potential (we've set up a dedicated team to support female founders and have issued a series of funding calls targeting women entrepreneurs and researchers from third-level institutions.)

The action plan has also set targets including increases in:

- the number of women-led companies growing internationally,

- the participation rate of women on Enterprise Ireland Management Development programmes,

- the number of women participants on start-up programmes,

- Local Enterprise Office supports to women in business, and

- the proportion of female-founded High-Potential Start-Ups.

In the Ireland for Finance Action Plan 2019, the Industry Advisory Committee (IAC) was tasked with developing a Women in Finance Charter (WIF Charter). The WIF Charter entails companies that sign the Charter committing to supporting the progression of women into senior roles in the financial services sector by focusing on the executive pipeline and mid-tier level positions. 
International comparators such as the UK's Women in Finance Charter, launched in March 2016, have been signed by more than 350 organisations covering 800,000 employees across the UK financial services sector. Ireland is aiming to build on this international example, and significant progress has been made.

In Action Plan 2020, the Irish finance industry committed to work on a similar charter or seek a suitable and up-to-date alternative and seek signatory organisations. The Irish Government has noted significant progress in this regard. On 8 March 2019, the Irish Government agreed to establish a public sector network within the $30 \%$ Club Ireland. This initiative, based on the $30 \%$ Club global campaign, offers opportunities to promote greater gender balance in the public sector, in addition to sharing good practices on promoting women in leadership between the public and corporate sectors.

Across all sectors in Ireland, the proportion of applications by women for approval for board-level positions increased from $20 \%$ in 2018 to $26 \%$ in 2019 . The proportion of women applying for approval for management-level positions was higher, but remained static at $29 \%$ in both 2018 and 2019. In 2021, the work on diversity and gender balance will continue, pressing to ensure diversity and gender balance is a priority and agenda point in international financial services firms. It is also important to continue to drive the agenda to the next level.

At the small and medium enterprise level, Ireland is also making a difference in supporting early-stage and female entrepreneurs and women in business. Through the nationwide programme, ACORNS, Irish female entrepreneurs in rural locations are given the opportunity to tap into the experience and mentorship of fellow female entrepreneurs. Ireland faces a similar challenge to China in coming up with ways to address the urban/rural divide, especially in terms of incentives for businesses outside the main commercial centres. Through this programme, Ireland has been able to successfully support its early-stage female entrepreneurs in growing their businesses.

Going for growth is another initiative introduced by the Irish government designed to support women in growing their own businesses. Participants are offered a unique learning environment with a peer-led approach based on the shared experiences of both a lead entrepreneur and other participants facing common challenges.

\section{International Financial Institutions}

Ireland-China cooperation in the sphere of economics and finance also extends to international financial institutions. Ireland became a member of the Asian Infrastructure Investment Bank (AIIB) in October 2017 and is a member of the Euro Area Constituency of the Bank along with other Euro Area AIIB members (Cyprus, Germany, France, Italy, Spain, Austria, Finland, Luxembourg, Malta, Netherlands and Portugal). 
Ireland very much values its membership of multilateral financial institutions such as the AIIB and fully supports its key aims of fostering economic development and regional integration in Asia.

AIIB membership also complements Ireland's international development policy, broadening the scope of our development assistance to Asia and aligning with priorities including sustainable development and inclusive economic growth.

Ireland and the other EU members of the AIIB are keen to ensure that the AIIB's innovative approach is complemented by robust governance standards on a par with other multilateral development banks.

\section{Conclusion}

Overall, cooperation between Ireland and China across the economic, trade and finance spectrum remains one of our strongest and fastest growing linkages. As our relationship in these areas continues to evolve, I am sure that both Ireland and China will be able to benefit from the growing fruits of our relationship.

As China becomes an ever more influential partner on the world stage and key member of the multilateral trading system, cooperation and engagement between our countries will become ever more important.

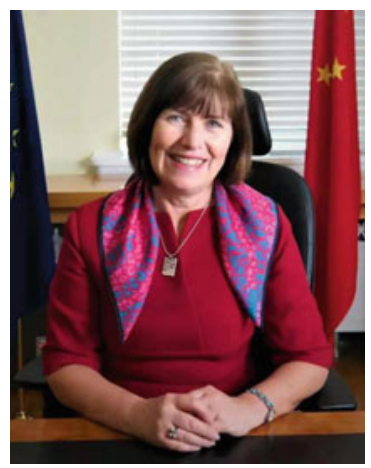

H.E. Ms. Ann Derwin is the ambassador of Ireland to the People's Republic of China. She has been the ambassador of Ireland to China (also accredited to Mongolia) since 2021. Ms. Derwin graduated from Queen's University Belfast/the Institute of Public Administration with a Doctorate degree in Governance. She joined the Irish Department of Agriculture and Food in 1992. From 1998 to 2002, she served as First Secretary in the Irish Embassy in Madrid. She became Superintending Veterinary Inspector in the Department of Agriculture and Food in 2004, a post she held until 2010 when she became Chief Economist, in 2015 she was appointed Assistant Secretary General. Before taking office in Beijing, she was Director General in Global Irish Services Division. 
Open Access This chapter is licensed under the terms of the Creative Commons AttributionNonCommercial-NoDerivatives 4.0 International License (http://creativecommons.org/licenses/bync-nd/4.0/), which permits any noncommercial use, sharing, distribution and reproduction in any medium or format, as long as you give appropriate credit to the original author(s) and the source, provide a link to the Creative Commons license and indicate if you modified the licensed material. You do not have permission under this license to share adapted material derived from this chapter or parts of it.

The images or other third party material in this chapter are included in the chapter's Creative Commons license, unless indicated otherwise in a credit line to the material. If material is not included in the chapter's Creative Commons license and your intended use is not permitted by statutory regulation or exceeds the permitted use, you will need to obtain permission directly from the copyright holder.

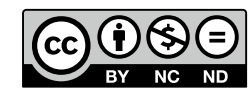

